\title{
In vitro mass multiplication of Jatropha (Jatropha curcas L.) through axillary bud culture
}

\author{
L.K. Behera", M. R. Nayak, D. Nayak and D.B. Jadeja \\ ASPEE College of Horticulture and Forestry, Navsari Agricultural University, Navsari- 396450 (Gujarat), INDIA \\ *Corresponding author. E-mail: 1kbehera@ nau.in
}

Received: March 31, 2014; Revised received: April 22, 2014; Accepted: May 2, 2014

\begin{abstract}
The present investigation was conducted for mass multiplication of Jatropha curcas L. through axillary bud culture. For this nodal segment from 3-5 months old nursery grown plants were used as explants for axillary bud culture. The sterilization treatment involving dipping explants in 0.1 per cent $\mathrm{HgCl}_{2}$ solution for 5 minutes resulted in minimum contamination and maximum establishment of nodal explants. The treatment MS medium supplemented with $1.0 \mathrm{mg} / \mathrm{L} \mathrm{BAP}$ and $1.0 \mathrm{mg} / \mathrm{L} \mathrm{IAA}$ was the best for culture establishment, shoot proliferation and multiplication of the axillary buds which exhibited highest value in each parameter like establishment $(76.1 \%)$, number of days taken for shoot initiation (3.1 days), length of longest shoot $(6.8 \mathrm{~cm})$, number of leaves on main shoot $(7.1)$ and number of shoots per explant (6.3). Among different treatments for root initiation, half MS media fortified with $1 \mathrm{mg} / \mathrm{L} \mathrm{IBA}, 3 \mathrm{mg} /$ L NAA and $0.25 \mathrm{~g} \mathrm{AC}$ gave best result in maximum number of rooting percentage (60) with minimum time taken for root initiation (13.3 days), produced maximum number of roots per shoots (5.1) and length of longest root $(4.9 \mathrm{~cm})$ when established shoots were treated with it. Such produced plantlets showed nearly cent per cent survival after hardening and acclimatization. It showed that explants surface sterilized with 0.1 per cent $\mathrm{HgCl}_{2}$ solution for 5 minutes inoculated in MS medium supplemented with $1.0 \mathrm{mg} / \mathrm{L}$ BAP and $1.0 \mathrm{mg} / \mathrm{L}$ IAA and half MS media fortified with $1 \mathrm{mg} / \mathrm{L}$ IBA, $3 \mathrm{mg} / \mathrm{L}$ NAA and $0.25 \mathrm{~g}$ AC were best in shoot establishment and root development respectively for mass multiplication of $J$. curcas $L$. through axillary bud culture.
\end{abstract}

Keywords: Axillary bud culture, In vitro, Jatropha curcas, Mass multiplication, Plantlets

\section{INTRODUCTION}

Ratanjyot or physic nut scientifically named as Jatropha curcas L. member of Euphorbiaceae family has immense potential of producing Jatropha oil which has large scale industrial uses. Almost all parts of the plant including seeds, leaves, fruit, root and fresh leaves are used for traditional as well as modern medicinal uses. It also have the anticancerous properties because of the presence of alkaloid "Jatrophine" in latex (Thomas, et al., 2008). From its seeds, products are extracted that are useful for the production of insecticides (Silva et al., 2012), soap, candles and pesticides. Jatropha seed oil has high values of density, flash point, lubricity and calorific value comparable to diesel (Momin, 2013). Hence, it can be readily mixed with high-speed diesel and can be blended ranging from 5 to $20 \%$. It is also an environmentally safe, cost effective and renewable non-conventional source of energy as a promising substitute to hydel power, diesel, kerosene, L.P.G., coal and fuel wood etc. Direct saving of foreign exchange by reducing the import of petroleum products will improve our "Balance of payment (BOP)" and environmental balance will also be restored through massive plantations of Ratanjyot on degraded areas and waste lands (Patil and Singh, 1991).

Oil from Jatropha seeds seems to be a viable option in each respect. Therefore, a sustainable and commercially viable production technology needs to be evolved for higher seed yield and oil content of $J$. curcas. The average yield of J. curcas is about 4.0 to $6.0 \mathrm{~kg}$ air dry seeds from 5 years old plant. Since, planned cultivation of Jatropha has not been practiced for longer period or failed due to over estimation of yield in early 1 to 5 years; it is very difficult to identify the suitable planting materials and correctly estimate the yield. Jatropha plantation will be successful only when best quality planting material from selected clones or varieties are used and made available to farmers in large quantities. In vitro regeneration techniques offer a powerful tool for germplasm conservation, mass multiplication of true to type plants and genetic transformation (Kumar and Reddy, 2010). Further tissue culture through micropropagation is one of the best option through which true to type, fast growing, healthy, disease free, high yielding planting materials can be produced in large quantity in a short period. In view of need to address these issues in holistic manner, the present investigation was aimed to produce 
disease free, elite and healthy planting materials at rapid rate in sufficient quantity.

\section{MATERIALS AND METHODS}

Present investigation was carried out at the Plant Tissue Culture and Biotechnology Laboratory, ASPEE College of Horticulture and Forestry, Navsari Agricultural University, Navsari, Gujarat. Stem segments containing one node each were collected from 3 to 5 months old plants. These nodal segments were sterilized with Bavistin, Teepol and surface sterilization was carried out with various sterilants for different time period. The sterilized nodal segments were then cut and trimmed into small nodal explants of $1 \mathrm{~cm}$ length. Under aseptic condition, each explant was then quickly inoculated on the Murashige and Skoog (MS) medium supplemented with single or combination of growth regulators for establishment, proliferation and multiplication of shoot. For maximum multiplication of shoots, medium was maintained at $\mathrm{pH} 5.8$, sucrose 3 per cent and light intensity of 3000 lux. The established shoots were transferred to MS medium with different rooting hormones like NAA and IBA singly or in combination with or without Activated Charcoal (AC) for root development. Rooted plantlets were undergone acclimatization in the air conditioned room after removing agar carefully and dipping roots in 0.05 per cent Bavistin, planted in plastic pots containing pretreated soil, sand and Farm Yard Manure (FYM) $(1: 1: 1 \mathrm{~V} / \mathrm{V} / \mathrm{V})$ mixture and covered with polythene for 6-7 days. The cover was gradually removed after 7 days, initially for 3 hours followed by 6 hours and then 12 hours in next 3 days. The cover was removed during night and lights put-off for next 3-4 days. Subsequently, the period of keeping the plantlets without any cover was gradually increased and after 15 days they were brought outside the room in shade. Within next 10 days plantlets were gradually exposed to sun, so that they were acclimatized to natural environment. For analysis the treatment means (during optimizing parameters for mass multiplication of Jatropha) were compared using Completely
Randomized Design (CRD). The data were subjected to analysis of Variance (ANOVA) and treatment means were compared (Pense and Sukhatme, 1967) accordingly.

\section{RESULTS AND DISCUSSION}

Out of different treatments, $0.1 \% \mathrm{HgCl}_{2}$ for 5 minutes treatment for surface sterilization to the explants gave best sterilization and maximum establishment (82\%) of nodal explants (Table 1). It is obvious that sterilization treatment for explants collected from different age and stages of growth, may differ depending upon the environmental conditions of the area from where the explants are collected. The different locations may harbor different microflora with different intensity. Similar to present finding, Thakur and Shukla (2006) reported the effective surface sterilization of $J$. curcas nodal explants treating with $0.1 \% \mathrm{HgCl}_{2}$ for 10 minutes. Moreover the surface sterilization treatment must be effective in clearing the bacteria, fungi and other microbes harboured by the explants in the prevailing conditions. However, the effective treatment should not harm the explants. It is further evident from the data that treatment of $0.5 \%$ $\mathrm{HgCl}_{2}$ for same duration, effective in controlling the contamination but adversely affected the explants by killing more number of explants, thus confirming the previous report. Various treatments were tried for shoot bud establishment. The MS medium with $1.0 \mathrm{mg} / \mathrm{L}$ BAP and $1.0 \mathrm{mg} / \mathrm{L}$ IAA was found best among different treatments in the establishment of shoots and multiplication (Table 2). The result of this treatment showed highest value in each parameter like establishment $(76.1 \%)$, number of days taken for shoot initiation (3.1 days), length of longest shoot $(6.8 \mathrm{~cm})$, number of leaves on main shoot (7.1) and number of shoots per explant (6.3). Numerous plant species show morphogenesis with auxin/ cytokinin ratios. Generally BAP and kinetin have been used as cytokinin for regeneration of shoots in Jatropha where as BAP has been found to be more effective (Rajore and Batra, 2005).

NAA, IAA and IBA have been used as auxin. For

Table 1. Effect of different sterilant treatments on the axillary bud explants of J. curcas.

\begin{tabular}{|c|c|c|c|c|c|c|}
\hline \multirow[t]{2}{*}{ S.N. } & \multicolumn{3}{|c|}{ Treatments } & \multirow{2}{*}{$\begin{array}{c}\text { Contamination } \\
(\%)\end{array}$} & \multirow{2}{*}{$\begin{array}{c}\text { Death of } \\
\text { culture }(\%)\end{array}$} & \multirow{2}{*}{$\begin{array}{c}\text { Establishment } \\
(\%)\end{array}$} \\
\hline & Sterilants & $\begin{array}{c}\text { Concentration } \\
(\%)\end{array}$ & $\begin{array}{l}\text { Duration } \\
\text { (minutes) }\end{array}$ & & & \\
\hline $\mathrm{T}_{1}$ & $\mathrm{HgCl}_{2}$ & 0.1 & 3 & 45 & 5 & 50 \\
\hline $\mathrm{T}_{2}$ & $\mathrm{HgCl}_{2}$ & 0.1 & 5 & 10 & 8 & 82 \\
\hline $\mathrm{T}_{3}$ & $\mathrm{HgCl}_{2}$ & 0.5 & 5 & 15 & 10 & 75 \\
\hline $\mathrm{T}_{4}$ & $\mathrm{AgNO}_{3}$ & 0.1 & 5 & 60 & 5 & 35 \\
\hline $\mathrm{T}_{5}$ & $\mathrm{AgNO}_{3}$ & 0.5 & 10 & 50 & 10 & 40 \\
\hline $\mathrm{T}_{6}$ & $\mathrm{NaClO}$ & 0.5 & 10 & 80 & 5 & 15 \\
\hline $\mathrm{T}_{7}$ & $\mathrm{NaClO}$ & 1.0 & 10 & 65 & 10 & 25 \\
\hline
\end{tabular}

MS Medium, Observations after $3^{\text {rd }}$ week 
Table 2. Effect of BAP, KN and IAA on culture establishment and multiplication of shoot from the axillary bud explants curcas.

\begin{tabular}{|c|c|c|c|c|c|c|c|}
\hline \multicolumn{3}{|c|}{$\begin{array}{r}\text { Treatments } \\
\end{array}$} & \multirow{2}{*}{$\begin{array}{c}\% \\
\text { Establishment }\end{array}$} & \multirow{2}{*}{$\begin{array}{c}\text { No. of days } \\
\text { taken for shoot } \\
\text { initiation }\end{array}$} & \multirow{2}{*}{$\begin{array}{c}\text { Length of } \\
\text { longest } \\
\text { shoot }(\mathrm{cm})\end{array}$} & \multirow{2}{*}{$\begin{array}{l}\text { No. of } \\
\text { leaves }\end{array}$} & \multirow{2}{*}{$\begin{array}{l}\text { No. of shoots } \\
\text { per explant }\end{array}$} \\
\hline $\begin{array}{c}\text { BAP } \\
(\mathrm{mg} / \mathrm{L})\end{array}$ & $\begin{array}{c}\mathbf{K N} \\
(\mathrm{mg} / \mathrm{L})\end{array}$ & $\begin{array}{c}\text { IAA } \\
(\mathbf{m g} / \mathbf{L})\end{array}$ & & & & & \\
\hline 0.0 & 0.0 & 0.0 & 64.6 & 5.3 & 6.1 & 2.1 & 2.2 \\
\hline 0.5 & 0.0 & 0.0 & 67.4 & 4.2 & 5.2 & 5.2 & 4.4 \\
\hline 1.0 & 0.0 & 0.0 & 69.6 & 4.4 & 4.3 & 3.9 & 3.1 \\
\hline 2.0 & 0.0 & 0.0 & 68.3 & 5.7 & 5.2 & 2.2 & 2.7 \\
\hline 5.0 & 0.0 & 0.0 & 61.2 & 4.3 & 3.0 & 2.3 & 2.1 \\
\hline 0.5 & 0.5 & 0.0 & 65.4 & 4.5 & 2.7 & 4.4 & 3.5 \\
\hline 1.0 & 0.5 & 0.0 & 67.8 & 5.4 & 3.3 & 4.5 & 4.6 \\
\hline 2.0 & 0.5 & 0.0 & 62.9 & 7.4 & 5.1 & 3.2 & 2.3 \\
\hline 0.5 & 1.0 & 0.0 & 66.3 & 6.3 & 3.1 & 3.6 & 2.5 \\
\hline 1.0 & 1.0 & 0.0 & 65.2 & 5.5 & 4.2 & 4.9 & 3.2 \\
\hline 2.0 & 1.0 & 0.0 & 63.8 & 5.4 & 5.3 & 4.3 & 3.8 \\
\hline 0.5 & 2.0 & 0.0 & 61.1 & 6.4 & 5.0 & 3.0 & 2.7 \\
\hline 1.0 & 2.0 & 0.0 & 60.4 & 6.5 & 6.1 & 2.6 & 2.5 \\
\hline 2.0 & 2.0 & 0.0 & 58.2 & 8.1 & 5.2 & 2.2 & 1.9 \\
\hline 1.0 & 0.0 & 1.0 & 76.1 & 3.1 & 6.8 & 7.1 & 6.3 \\
\hline 2.0 & 0.0 & 1.0 & 73.6 & 4.3 & 6.0 & 5.3 & 4.5 \\
\hline 1.0 & 0.0 & 2.0 & 71.2 & 4.1 & 5.6 & 6.2 & 5.1 \\
\hline 2.0 & 0.0 & 2.0 & 67.5 & 7.7 & 3.9 & 3.3 & 2.6 \\
\hline $\mathrm{SEm} \pm$ & & & 0.95 & 0.72 & 0.75 & 0.32 & 0.23 \\
\hline C.D. $(5 \%$ & & & 2.73 & 2.07 & 2.14 & 0.92 & 0.67 \\
\hline C.V.\% & & & 0.14 & 1.27 & 1.48 & 0.79 & 0.68 \\
\hline
\end{tabular}

Basal Medium $=$ MS, Culture period $=4$ week

Table 3. Effect of different rooting treatments on in vitro regenerated shoots of J. curcas.

\begin{tabular}{|c|c|c|c|c|}
\hline Treatments & $\begin{array}{c}\text { Rooting } \\
(\%)\end{array}$ & $\begin{array}{l}\text { No. of days taken } \\
\text { for root initiation }\end{array}$ & $\begin{array}{l}\text { No. of roots } \\
\text { per shoots }\end{array}$ & $\begin{array}{l}\text { Length of long- } \\
\text { est } \operatorname{root}(\mathrm{cm})\end{array}$ \\
\hline Half MS + $1 \mathrm{mg} / \mathrm{L} \mathrm{NAA}$ & 35 & 30.7 & 1.2 & 2.0 \\
\hline Half MS $+3 \mathrm{mg} / \mathrm{L} \mathrm{NAA}$ & 40 & 23.6 & 2.0 & 2.3 \\
\hline Half MS + $5 \mathrm{mg} / \mathrm{L}$ NAA & 30 & 18.5 & 2.5 & 2.7 \\
\hline $\begin{array}{l}\text { Half } \mathrm{MS}+1 \mathrm{mg} / \mathrm{L} \mathrm{IBA}+1 \mathrm{mg} / \mathrm{L} \mathrm{NAA} \\
+0.25 \mathrm{~g} \mathrm{AC}\end{array}$ & 40 & 17.0 & 1.8 & 2.2 \\
\hline $\begin{array}{l}\text { Half } \mathrm{MS}+1 \mathrm{mg} / \mathrm{L} \mathrm{IBA}+3 \mathrm{mg} / \mathrm{L} \mathrm{NAA} \\
+0.25 \mathrm{~g} \mathrm{AC}\end{array}$ & 60 & 13.3 & 5.1 & 4.9 \\
\hline $\begin{array}{l}\text { Half } \mathrm{MS}+1 \mathrm{mg} / \mathrm{L} \mathrm{IBA}+5 \mathrm{mg} / \mathrm{L} \mathrm{NAA} \\
+0.25 \mathrm{~g} \mathrm{AC}\end{array}$ & 45 & 15.3 & 2.7 & 2.1 \\
\hline $\begin{array}{l}\text { Half } \mathrm{MS}+3 \mathrm{mg} / \mathrm{L} \mathrm{IBA}+1 \mathrm{mg} / \mathrm{L} \mathrm{NAA} \\
+0.25 \mathrm{~g} \mathrm{AC}\end{array}$ & 15 & 20.2 & 2.9 & 1.5 \\
\hline $\begin{array}{l}\text { Half } \mathrm{MS}+3 \mathrm{mg} / \mathrm{L} \mathrm{IBA}+3 \mathrm{mg} / \mathrm{L} \mathrm{NAA} \\
+0.25 \mathrm{~g} \mathrm{AC}\end{array}$ & 25 & 22.5 & 4.1 & 1.8 \\
\hline
\end{tabular}

Observations after $3^{\text {rd }}$ week

axillary shoot proliferation and regeneration MS medium supplemented with $1.0 \mathrm{mg} / \mathrm{L} \mathrm{BAP}$ and $1.0 \mathrm{mg} /$ L IAA responded best and produced longest, multiple shoots. The present finding was in agreement with Thakur and Shukla (2006). Out of different treatments tried for root development, half strength MS medium with $1.0 \mathrm{mg} / \mathrm{L} \mathrm{IBA}, 3.0 \mathrm{mg} / \mathrm{L}$ NAA and $0.25 \mathrm{~g} \mathrm{AC}$ produced maximum number of rooting percentage (60) with minimum time for root initiation (13.3 days), which ultimately produced maximum number of roots per shoots (5.1) and length of longest root $(4.9 \mathrm{~cm})$.In J. curcas, Batra et al. (2000) found $60-80 \%$ rooting response in half strength $\mathrm{MS}$ with $5 \mathrm{mg} / \mathrm{L}$ NAA.
Similarly, Thakur and Shukla (2006) found the best result of rooting in half strength MS with $1.0 \mathrm{mg} / \mathrm{L}$ IBA, $3.0 \mathrm{mg} / \mathrm{L}$ NAA and $0.25 \mathrm{~g} / \mathrm{l} \mathrm{AC}$. The high rooting success in all respect is comparable to those of earlier findings. Addition of activated charcoal to the rooting medium was found to improve rooting. The positive response of activated charcoal on rooting may be attributed to the known fact that activated charcoal absorbs phenolic compounds and extra concentration of growth hormones from the medium thus reducing their inhibitory effect on rooting processes. Transplanting was done when the plantlets had well developed 3-4 roots and 4-5 leaves. Such plantlets 
showed nearly cent percent survival during hardening and acclimatization. These observations are supported by various earlier workers (Sujatha and Mukta, 1996; Batra et al., 2000 and Sardana et al., 2000).

\section{Conclusion}

It was concluded that nodal explants collected from 35 months old plants produced numerous plantlets in in vitro condition when surface sterilized was carried out with $0.1 \% \mathrm{HgCl}_{2}$ for 5 minutes, inoculated in MS medium with $1.0 \mathrm{mg} / \mathrm{L} \mathrm{BAP}$ and $1.0 \mathrm{mg} / \mathrm{L}$ IAA for establishment, proliferation and multiplication of shoot. The established shoots developed maximum roots in half strength MS medium with $1.0 \mathrm{mg} / \mathrm{lBA}$, $3.0 \mathrm{mg} / \mathrm{l} \mathrm{NAA}$ and $0.25 \mathrm{~g} \mathrm{AC}$. Such produced plantlets showed nearly cent percent survival during hardening and acclimatization.

\section{REFERENCES}

Batra, A., Sardhana, J. and Julfikar, D. A. (2000). High efficiency propagation of Jatropha curcas L.: A medicinally potent plant species. Role of Biotechnology in Medicinal and Aromatic plants, Ukaaz Publication, Hyderabad, pp. 274-285.

Kumar, N. and Reddy, M.P. (2010). Plant regeneration through the direct induction of shoot buds from petiole explants of Jatropha curcas: a biofuel plant. Annals of Applied Biology, 156: 367-375.
Momin, G.G. (2013). Experimental investigation on Jatropha oil as a biodiesel fuel with analysis of its emission characteristics. International Journal of Research in Advent Technology, 1(4): 102-110.

Panse, V.G. and Sukhatme, P.V. (1967). Statistical methods for agricultural workers. Indian Council of Agricultural Research, New Delhi.

Patil, V. and Singh, K. (1991). Oil Gloom to Oil Boom Jatropha curcas-A promising agro-forestry crop. Agro-forestry federation, Maharashtra and Ministry of Environment and Forest, New Delhi.

Rajore, S. and Batra, A. (2005). Efficient plant regeneration via shoot tip explant in Jatropha curcas L. Journal of Plant Biochemistry and Biotechnology, 14(1): 73-75.

Sardana, J., Batra, A. and Ali, D. J. (2000). An expeditious method for regeneration of somatic embryos in Jatropha curcas L. Phytomorphology, 50(3/4): 239-242.

Silva, G. N., Faroni, L. R. A., Sousa, A. H. and Freitas, R. S. (2012). Bioactivity of Jatropha curcas L. to insect pests of stored products. Journal of Stored Products Research, 48: 111-113.

Sujatha, M. and Mukta, N. (1996). Morphogenesis and plant regeneration from tissue cultures of Jatropha curcas. Plant cell, Tissue and Organ Culture, 44(2): 135-141.

Thakur, S. K. and Shukla, S. V. (2006). Mass multiplication of Jatropha curcas L. through micropropagation. Indian Journal of Agroforestry, 8(2):32-37.

Thomas, R., Sah, N.K. and Sharma, P.B. (2008). Therapeutic biology of Jatropha curcas; a mini review. Current Pharmaceutical Biotechnology, 9(4): 315-324. 